\title{
MYCORRHIZAL GROWTH RESPONSE AND GLOMALIN PRODUCTION EFFECTED BY ARBUSCULAR MYCORRHIZAL FUNGI (AMF) AND NITROGEN OF ORGANIC MATERIALS ON CORN
}

\author{
Eddiwal $^{1,2} *$, Amrizal Saidi ${ }^{1}$, Eti Farda Husin ${ }^{1}$ and Azwar Rasyidin ${ }^{1}$ \\ ${ }^{1}$ Postgraduate Program, Andalas University Padang \\ ${ }^{2}$ Faculty of Agriculture, Islamic University of Western Sumatra
}

*Corresponding author :edwals.edu2@gmail.com

Received : 4 Mei 2015 Accepted : 2 Desember 2015

\begin{abstract}
Symbiotic relationships between arbuscular mycorrhizal fungi (AMF) and plants can increase the capacity of plants to absorb nutrients and water from the soil by exploring micropores not accessible to plant roots. The arbuscular mycorrhizal symbiosis between plants and soil fungi improves phosphorus and nitrogen acquisition under limiting conditions. Recent discoveries indicate that AMF hyphae containing glomalin as glycoproteins and function unitinge the soil particles to form stable soil aggregates. Glomalin acts as an adhesive (glue) produced by AMF symbiosis with the host plant. The AMF is capable of taking nitrogen and other nutrients from a source of organic materials to produce glomalin which is transferred to the host plant. The study was conducted using nitrogen from forage materials of Tithonia (Tithonia difersifolia) which the AMF needs to produce glomalin. This study assess the need for organic $\mathrm{N}$ by AMF to the mycorrhizal growth effect and its effects on glomalin. The study use sterile medium sand and zeolite mixture (w/w 1:1) in pot culture experiments with the corn as the host. For treatments using $\mathrm{N}$ derived from Tithonia are five doses, namely $0,10,20,30$, and $40 \mathrm{mg}$ of $\mathrm{N}$ Tithonia each pot. At the time of planting, the corn roots inoculated with AMF spores of the two species, namely Glomus luteum and Glomus versiforme. We show that a positive mycorrhizal growth response (MGR) was observed only in the dose of range 20 to $30 \mathrm{mg} \mathrm{N}$. This response did not appear to be affected by high nitrogen supply. Our results also show that in Glomus luteum at the dose of $20 \mathrm{mg} \mathrm{N}$ produce glomalin highest, namely $2.60 \mathrm{mg} \cdot \mathrm{g}^{-1}$ in the planting medium. Glomus versiforme has produced glomalin is $2.38 \mathrm{mg} \cdot \mathrm{g}^{-1}$ at the dose of $30 \mathrm{mg} \mathrm{N}$. The AMF species did not significantly affect the results of glomalin, while the use of $\mathrm{N}$ from forage materials of Tithonia significantly influenced the production of glomalin.
\end{abstract}

Keywords: glomalin, glycoprotein, mycorrhizal growth response, symbiotic.

\section{INTRODUCTION}

Problems in agricultural soils and difficult to deal with land management efforts, either through tillage or fertilization, can be overcome through improved soil physical properties (Subowo, 2010). Soil structure is a key factor in the functioning of the soil, which supports plant life and soil organisms (Bronick and Lal, 2005). Soil structure is used as an indicator of soil aggregate stability (Six et al., 2000). Soil aggregate stability was positively correlated with the amount of glomalin in the soil (Wright and Upadhyaya, 1998; Rillig, 2004; Curaqueo et al., 2010). Carrizo et al., (2015) has concluded that soluble carbohydrates and proteins associated with glomalin are the most important aggregation agents and their function is to reduce the amount of damage mechanisms, slaking and micro cracks, which affects silty soil.

Glomalin is produced by Arbuscular Mycorrhizal Fungi (AMF) associated with plant roots. Glomalin is specifically related to the combination of nitrogen $(\mathrm{N})$ as a glycoprotein that is contained within the walls of hyphae and spores of AMF found in the soil and roots (Wright and Upadhyaya, 1996; Driver et al., 2005; Rosier et al., 2008). Arbuscular mycorrhiza forms symbiotic mutualism with plant roots characterized by the exchange of nutrients, such as phosphorus $(\mathrm{P})$ and nitrogen $(\mathrm{N})$ from the fungi and carbon (C) of the host plant (Tian et al., 2010; Fellbaum et al., 2012; Nouri et al., 2014). AMF symbiosis between plants with fungi increase the procurement of $\mathrm{P}$ and $\mathrm{N}$ to the host under conditions of 
limited availability in the soil (Nouri et al., 2014). Fellbaum et al., (2012) explained that the fungus AM interact simultaneously in a network of hyphae with multiple hosts of different plant species, and because it does not rely on a single host to supply their C. Simbiotic systems of the plants showed that AMF will allocate the source of $\mathrm{N}$ and $\mathrm{P}$ in the network of hyphae to host plants that have provided $\mathrm{C}$ more to AMF. (Sisten simbiotic tanaman menunjukkan bahwa amf akan mengalokasikan sumber $\mathrm{N}$ dan $\mathrm{P}$ dalam jaringan hifa untuk tanaman inang yang telah menyediakan $\mathrm{Clebih}$ banyak untuk amf).

The main components of glomalin are an amino polysaccharide as sugar from plant roots and proteins from fungi forming glycoprotein (Wright et al., 2001; Hoorman, 2011). Metabolism of glomalin by AMF requires organic material as a source of $\mathrm{N}$ and procurement of $\mathrm{C}$ as an energy source of the host plant photosynthate results for metabolic needs. The growth of fungal hyphae increased due to $\mathrm{N}$ from organic materials and these are not dependent on its host (Hodge, Campbell and Fitter, 2001; Hodge and Fitter, 2010).

Intake of organic $\mathrm{N}$ is important in $\mathrm{AMF}$ symbiosis between fungi and plants, and the greater part of the AMF is able to take inorganic $\mathrm{N}$ from organic sources (Leigh et al., 2009). Nitrogen taken up by the intraradical mycelium of sources of organic matter can be in organic or inorganic forms (Guether et al., 2009). Nitrogen from organic sources is used for its own metabolism (Hodge and Fitter, 2010) and partially $(\sim 3 \% \mathrm{~N})$ transferred to the host plant (Hodge et al., 2001; Govindarajulu et al 2005; Cappellazzo et al., 2008; Leigh et al., 2009; Kobae et al., 2010; Hodge and Fitter, 2010). However, the availability of inorganic $\mathrm{N}$ and $\mathrm{P}$ can affect the development of the AMF. This is based on the findings of Nouri et al. (2014) that among all the nutrients tested, only nitrate and inorganic P (Pi) have a negative effect on AMF, while other major nutrients such as potassium $(\mathrm{K})$, calcium $(\mathrm{Ca})$, magnesium $(\mathrm{Mg})$, sulfate (SO4), and iron ( $\mathrm{Fe}$ ) have no effect on $\mathrm{AMF}$ at high concentrations. The effect of $\mathrm{N}$ from organic sources on AMF to produce glomalin and mycorrhizal growth has not been reported.

Our study evaluates how $\mathrm{N}$ from organic sources increases glomalin production and its influence on the AMF and the response of plant growth. The experiments tests what level of $\mathrm{N}$ from Tithonia forage material (Tithonia difersifolia) enables AMF to produce most glomalin. The role of organic material on the development of AMF and the response to plant growth (MGR = mycorrhizal growth response) is also studied. Our hypothesis is organic material can improve the development of AMF and increase glomalin production, thus providing a good growth response in the plants. The purpose of this research is to identify the optimum dose of organic $\mathrm{N}$ from Tithonia forage material that enables AMF to produce glomalin to support plant growth.

\section{METHODOLOGY}

\section{Organic materials, AMF inoculants and planting media}

Organic materials were given as a fine powder of T. diversifolia forage taken from the upper 50 $\mathrm{cm}$ branch. The forage material was dried at $65^{\circ} \mathrm{C}$ for 24 hours and, ground into a fine powder. The $\mathrm{N}$ content was measured to calculate the dose of treatment to be used. The results of the analysis showed $3.08 \% \mathrm{~N}$, which was the amount of the provision of forage material Tithonia used in the treatments such as Table 1. Inoculation AMF is G. luteum and G. versiforme obtained from Ultisol indigenous isolates that have been used in our previous experiments (Eddiwal et al., 2014). The AMF spore inoculant material used 30 spores per plant and were inoculated on corn roots that have germinated. Planting medium was a mixture of fine sand and zeolite $(\mathrm{w} / \mathrm{w} 1: 1)$ autoclaved at $121^{\circ} \mathrm{C}$ for $15 \mathrm{~min}$ and placed in $15 \mathrm{~cm}$ diameter pots using a nylon mesh (pot culturing glomalin). The experiment was conducted in a greenhouse to provide nutrient solution every week.

\section{Pot culturing glomalin}

Glomalin pot culture designed by Wright et al., (1996); Wright and Upadhyaya, (1996); Wright and Upadhyaya, (1999); Nichols and Wright, (2004) (online www.ars.usda.gov) with modifications. Nylon mesh was cut into 10-11 in. diameter circles (1/pot) and placed in sterilized pots, graduated cylinders, cups or beakers, and in mesh squares, in $10 \% \mathrm{NaOCl}$ for at least $1 \mathrm{hr}$, rinsed thoroughly with 
distilled water and dry covered. The media mix of sand and zeolite sterilized by autoclave for $1 \mathrm{hr}$ at $121^{\circ}$ $\mathrm{C}$ as with the potting media. The sand needs to be pre-extracted for glomalin by covering with $50 \mathrm{mM}$ sodium citrate, $\mathrm{pH} 8.0$, and autoclaving for $1 \mathrm{hr}$ at $121^{\circ} \mathrm{C} .300 \mathrm{ml}$ of potting media was place in a graduated cylinder and the nylon mesh circle was place over the top of the cylinder, secured with a rubber band near the top of the mesh (Figure. 1a). The cylinder was inverted over the center of the pot and filled around with potting media using a cup or beaker (Figure. 1b). The rubber band was released and carefully pulled out from the cylinder. The nylon mesh formed a seamless bag that separated plant roots from the surrounding media, forming a root/hyphal compartment (rhizosphere) and a hyphal compartment (mycorrhizosphere). The PVC pipe diameter 1 was placed in the two sides of $2 \mathrm{~cm}$ of nylon mesh (mycorrhizosphere) at a depth of $8 \mathrm{~cm}$ and $2 \mathrm{~cm}$ from the mesh barrier to placement of the treatment of organic matter in the third week (Figure. 1c). A hole was made in the center of the media in the mesh bag, ca. $2 \mathrm{~cm}$ deep and 2 plantlates of corn with spore inoculation were planted into this. This was covered with media and watered by hand over the mesh ring.

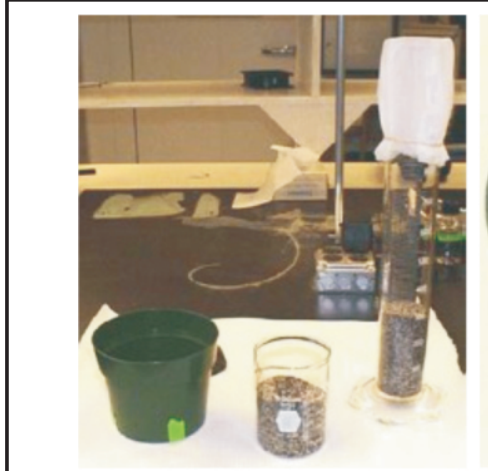

(a)

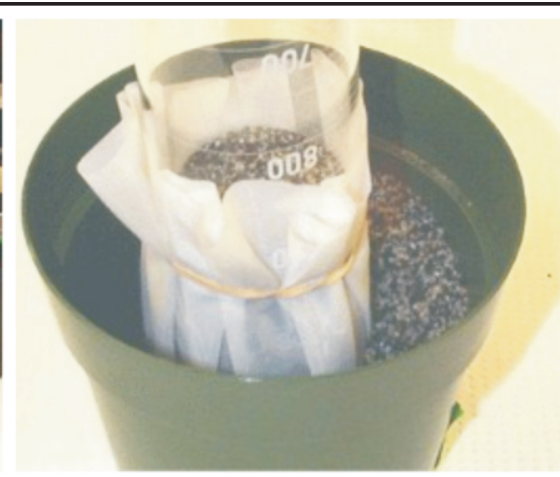

(b)

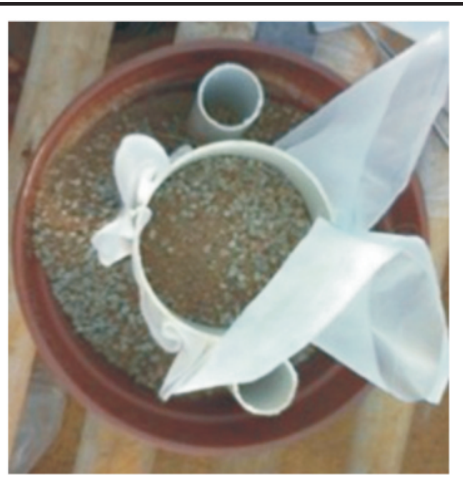

(c)

Figure 1. Placement of nylon mesh and filling the planting medium

\section{Experimental design and treatments}

The experiments was conducted using 2 x 5 factorial design with three replications. The first factor was the treatment of AMF species, namely: F $1=\mathrm{G}$. luteum; F2 $=\mathrm{G}$. versiforme. The second factor was the rate of $\mathrm{N}$ treatment of forage Tithonia (Table 1), namely: $\mathrm{T} 0=0 \mathrm{mg} ; \mathrm{T} 1=10 \mathrm{mg} ; \mathrm{T} 2=20$ $\mathrm{mg}$, T $3=30 \mathrm{mg}$ and T4 $=40 \mathrm{mg}$. Plants without AMF inoculation and organic matter were used as control plants. Experiments were conducted using a mixture of sand and zeolite media (W/W 1:1) with corn as a host in the set up in the greenhouse.

Table 1. The dosage of Tithonia

\begin{tabular}{lccccc}
\hline \multicolumn{1}{c}{ Treatments } & T0 & T1 & T2 & T3 & T4 \\
\hline Doses of N (mg) & 0 & 10 & 20 & 30 & 40 \\
Doses of tithonia (mg) & 0 & 325 & 650 & 975 & 1300 \\
\hline
\end{tabular}

Corn seeds germinated on moist cloth after 5 days, so that the roots appear 5 to $8 \mathrm{~cm}$ (plantlets). The planlets corn were planted in the center of the pot (roots compartment) and inoculated with AMF treatment. Plantlets were inoculated with a spore suspension of $30 \mathrm{AMF}$ using a pipette. The sprouts root (radicle) were placed in the planting hole so that the tip of the roots collected at the bottom of the hole. Spore suspension were carefully placed on the along the roots with a pipette. In principle, the spores stick to the roots and accumulate in the root tip in the bottom of the hole. In the third week, the treatment of organic matter was given through the PCV pipe (hyphal compatment) and the PVC pipe removed and the hole was covered with the surrounding medium. The plants were maintained by watering every day and administering a nutrient solution (Osaki et al., 1997) once a week. 


\section{Determination of plant growth and AMF colonization}

The plants were harvested at the indicated time points (52 d) to determine the fresh weight of the shoot and the root. Root samples were taken to determine total intraradical root colonization. The shoots were dried $\left(24 \mathrm{~h}\right.$ at $\left.65^{\circ} \mathrm{C}\right)$ to determine leaf nutrient content. The shoot:root ratio (ratio S:R) was calculated by dividing the fresh weight of the shoot by the fresh weight of the root. The mycorrhizal growth response (MGR) was calculated as the ratio of the shoot fresh weights of mycorrhizal and nonmycorrhizal plants respectively. To aid comparison, the nutrient levels of the different treatments were normalized to the respective controls that were set at $100 \%$ (Nouri et al., 2014). The root samples were cleaned by immersing in $10 \% \mathrm{KOH}$, neutralized with $1 \% \mathrm{HCl}$ and tinged with blue tryphan, as described by Kormanik and McGraw (1982). The percentage of root colonization by fungi presence arbuscular and vesicles were observed with an optical microscope at a magnification of $100 \mathrm{x}$. Percentase colonization was counted for each sample using the method described by Giovannetti and Mosse (1980).

\section{Determination of total glomalin}

Samples of the planting medium were used to determine total glomalin. Total glomalin was calculated as the amount of protein $(\mathrm{mg})$ measured in $1 \mathrm{~g}$ of the media. Total glomalin was analysed using the Bradford protein assay method with modification of sodium pyrophosphate, published (online) by the USDA (www.ars.usda.gov). Briefly $1.0 \mathrm{~g}$ sample of the media in $8 \mathrm{~mL}$ of $100 \mathrm{mM}$ sodium pyrophosphate $\left(\mathrm{Na}_{4} \mathrm{P}_{2} \mathrm{O}_{7} \cdot 10 \mathrm{H}_{2} \mathrm{O}\right), \mathrm{pH} 9.0$ and at a temperature of $121^{\circ} \mathrm{C}$ diautocalve for 1 hour. Samples were centrifuged $5000 \mathrm{rpm}$ for $15 \mathrm{~min}$, the supernatant was transferred into a $50 \mathrm{ml}$ tube, and repeated up to 3 times until the supernatant was yellowish (straw-colored or colorless). All supernatants were combined and measuring the volume of the extract, then centrifuged 10,000 rpm for 10 minutes. $1.0 \mathrm{~mL}$ of the supernatant was transfered into a microtube to measure glomalin content. Glomalin concentration was measured by Bradford protein assay using BSA (bovine serum albumin) as standard. Measurements were performed in $200 \mu \mathrm{L}$ of PBS (phosphate buffered saline) was added $10 \mu \mathrm{L}$ of BioRad dye reagent Coomassie Brilliant Blue R - 250 (produced by Bio - Rad Laboratories. Inc.). Color reaction was read with a microplate reader at a wavelength of $595 \mathrm{~nm}$ (nano meter) after 5 minutes. Optical density was measured and compared with a standard curve of known concentrations of BSA $(1.25-5.0 \mu \mathrm{L})$. In the standard solution, PBS reduced by the addition of $100 \mathrm{mM}$ sodium pyrophosphate which is equivalent to the volume of the sample ( $200 \mu \mathrm{LPBS}$ - the volume of the sample).

\section{Statistical Analyses}

Statistical analyses were performed using Program CooStat versi 8.0. Data sets that satisfied normality and homoscedasticity criteria were compared using the Student's t-test or analysis of variance (ANOVA) followed by the Fisher's least significant difference (LSD) tests.

\section{RESULTS}

\section{Plant growth and AMF colonization}

AMF colonization and plant growth is influenced by the dose of $\mathrm{N}$ application Tithonia. The shoot and root weight and root colonization is determined by the age 52 days after planting. The ratio of shoot and root fresh weight (S: R ratio) of G. luteum is higher than in G. versiforme (Fig. 2a), but both species are highest at the maximum dose of $20 \mathrm{mg} \mathrm{N}$ to $\mathrm{S}: \mathrm{R}$ ratio. Mycorrhizal growth response was significantly different between the two species, G. versiforme higher than the other. A positive mycorrhizal growth response (MGR) was observed only in the level 20 to $30 \mathrm{mg} \mathrm{N}$ and significantly different with other doses. The increase in the provision of organic $\mathrm{N}$ to $40 \mathrm{mg} \mathrm{N}$ actually reduced MGR (Fig. 2b), which indicates that the plant is not profiting from an increase in the dose of organic $\mathrm{N}$ when inoculated with AMF. At the dose of $20 \mathrm{mg} \mathrm{N}$, MGR of G. versiforme is the highest of 2.72 but was not significantly different from $\mathrm{G}$. luteum (2.41). Increasing the dose of $\mathrm{N}$ to $40 \mathrm{mg}$ significantly reduced the value of MGR and the same thing happened to the reduction of the dose of $\mathrm{N}$. 


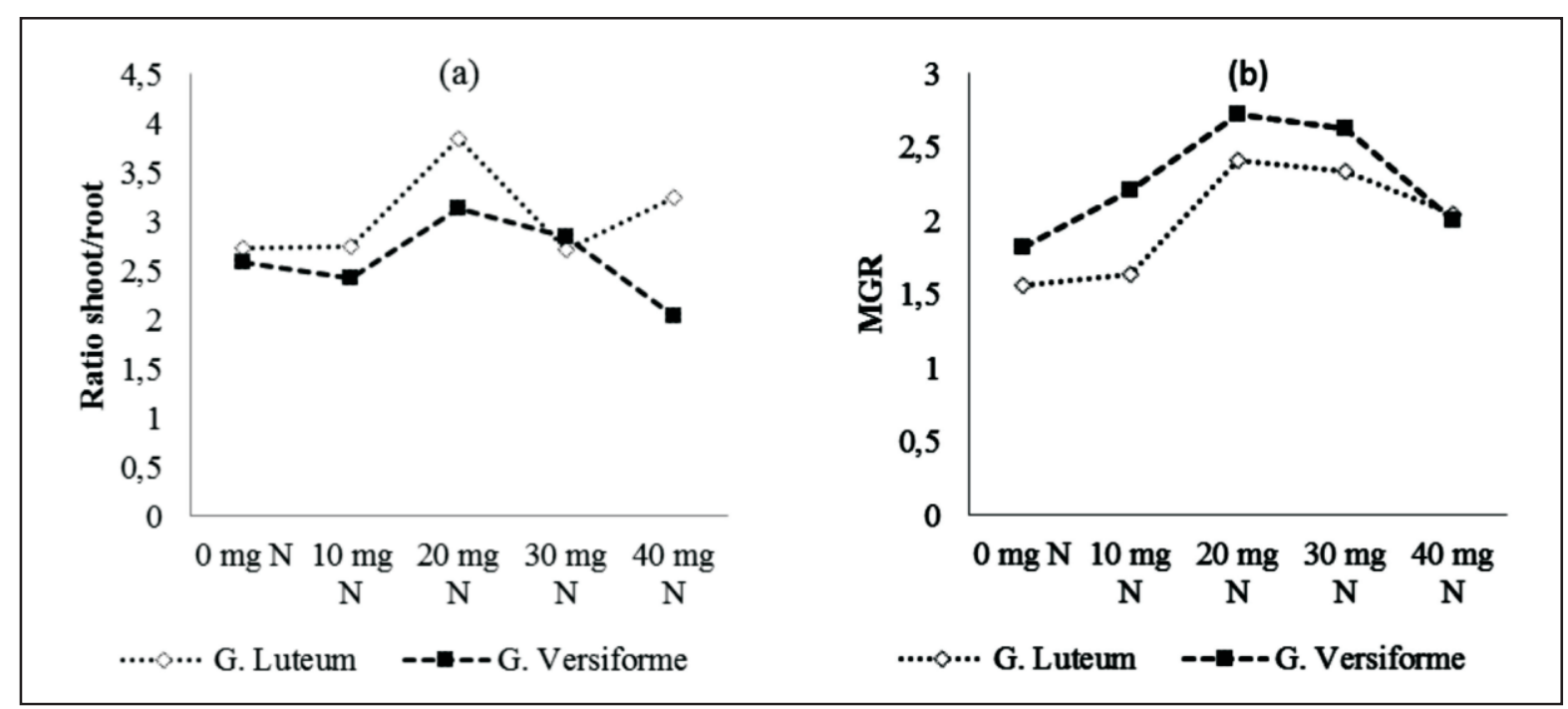

Figure 2. The growth of plant based organic $\mathrm{N}$ different doses. (a) shoot / root ratio of plants inoculated with G. luteum (white boxs) and G. versiforme (black boxs). (b) mycorrhizal growth response (MGR). MGR is defined as the ratio of the shoot weight of mycorrhizal versus non-mycorrhizal control plants.

AMF inoculation did not significantly affect to root colonization (Table 2). G. versivorme found higher colonization is $51.70 \%$. Furthermore, the influence of the organic $\mathrm{N}$ dose of Tithonia to root colonization indicates that the dose of $20 \mathrm{mg}$ of $\mathrm{N}$ resulted in the percentage of infection at the highest root, ie $66.58 \%$. This result is the same effect as giving $30 \mathrm{mg}$ of $\mathrm{N}$ Tithonia $(62.18 \%)$ and looks significantly different from the other doses. The influence of interactions between species of AMF and rate of $\mathrm{N}$ Tithonia to root colonization showed a very different effect of each treatment combination. In G. luteum by giving $20 \mathrm{mg} \mathrm{N}$ produced the highest root colonization by $73.20 \%$, while the highest colonization of G. versiforme is $74.27 \%$ with a dose of $30 \mathrm{mg} \mathrm{N}$.

The marked differences in the root colonization and MGR between $\mathrm{N}$ organic treatments meant it was necessary to evaluate the nutrient status of these plants. Nutrient status is as an indicator of plant fitness and qualitative mycorrhizal benefits. The effect of $\mathrm{N}$ organic on the content of nitrogen and phosphate in G. luteum and G. versiforme to non-mycorrhizal controls plants were determined (Fig. 3). Inoculation of AMF showed significant differences to nutrient contents in several $\mathrm{N}$ organic doses. $\mathrm{G}$. versiforme showed most significant on doses of 20 and $30 \mathrm{mg}$ for nitrogen and phosphorus content respectively, however G. luteum showed only most significant for phosphorus content on levels of 30 $\mathrm{mg}$. In contrast, zero doses of $\mathrm{N}$ organic were reduced in AMF inoculated relative to the nonmycorrhizal controls for nitrogen and phosphorus content (Figure 3a, 3b). Hence, in addition to the quantitative benefit in growth (Figure 2), mycorrhizal plants profited from a qualitative improvement in their nutrition (in particular of nitrogen and phosphorus). This results show that mycorrhizal plants profit, in addition to the mycorrhizal growth effect, from a qualitative benefit in nutrition. Hodge and Fitter (2010) also reported that P. lanceolata L. plants inoculated with G. hoi who were given organic N from materials of L. perenne L. forage dry oven as much as $1 \mathrm{~g}$ (containing $20.83 \mathrm{mg} \mathrm{N}$ ) labeled with $15 \mathrm{~N}$ and $13 \mathrm{C}$, occurs increase in stem growth and $\mathrm{N}$ content of stems and roots. Nearly $2 \%$ of $\mathrm{N}$ in the stem and $4.5 \% \mathrm{~N}$ in roots of mycorrhizal plants derived from organic matter, compared to plants without mycorrhiza only $1 \% \mathrm{~N}$ roots and the stem. 


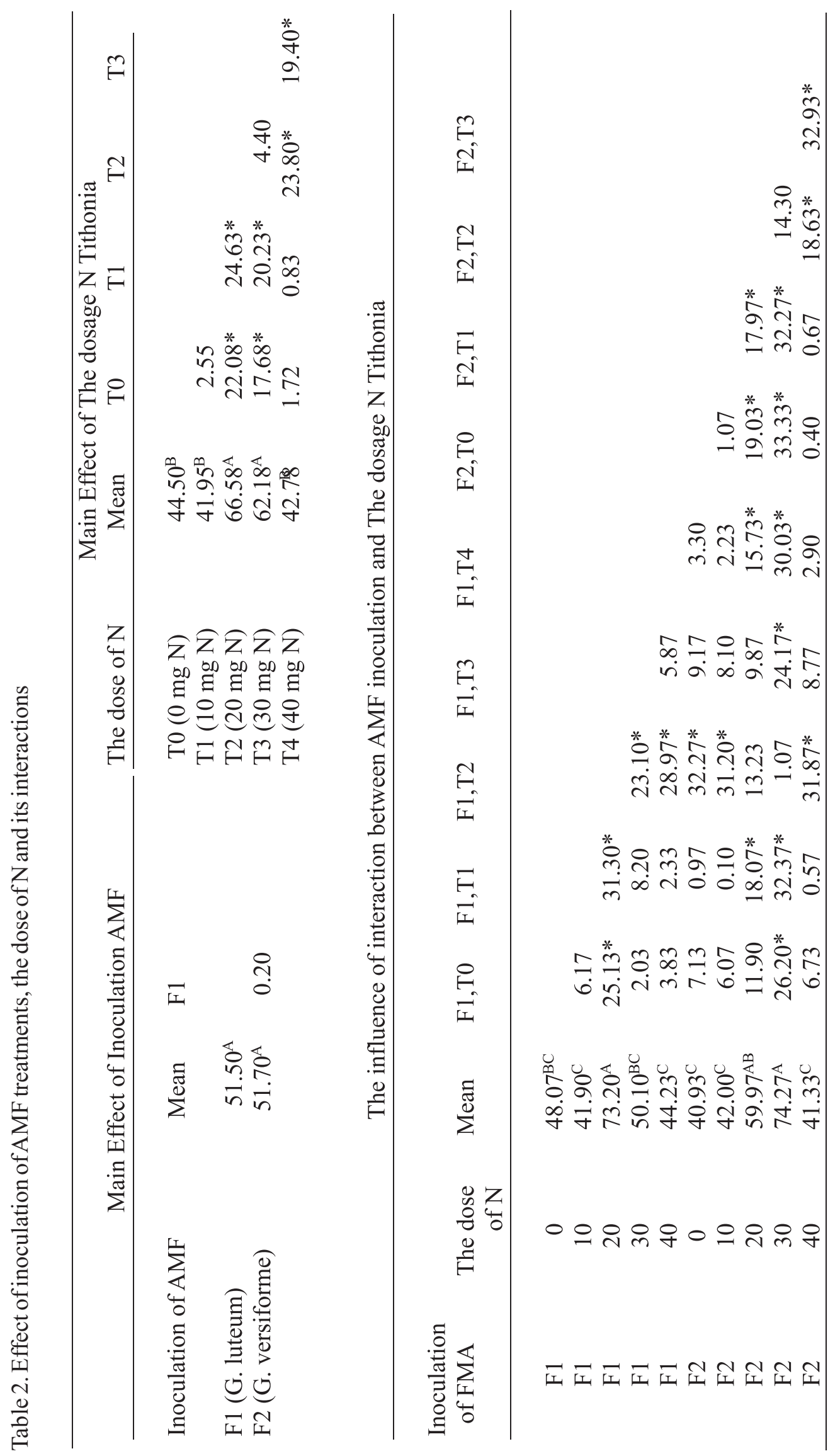




\section{Glomalin product by AMF}

AMF produced the highest glomalin G. versiforme ie $1.83 \mathrm{mg} . \mathrm{g}-1$. This treatment showed the same effect with the species $\mathrm{G}$. luteum. While the effect of the dose of organic $\mathrm{N}$ produced the highest glomalin at doses of $20 \mathrm{mg}$ of $\mathrm{N}$, ie $2.30 \mathrm{mg} . \mathrm{g}-1$ and the effect at the dose of $30 \mathrm{mg}$ N. The lowest glomalin production is at $0 \mathrm{mg} \mathrm{N}: 1.24 \mathrm{mg} . \mathrm{g}-1$.

The interaction between AMF and the rate of $\mathrm{N}$ Tithonia in glomalin production showed a very different effect of each treatment combination. The highest glomalin production (2.60 mg.g-1) is G. luteum with Tithonia dose of $20 \mathrm{mg}$ of $\mathrm{N}$ and did not differ significantly with $\mathrm{G}$ versiforme at doses of 30 $\mathrm{mg} \mathrm{N}$. The lowest glomalin production is G. versiforme (1.14 mg.g-1) with a dose of $0 \mathrm{mg} \mathrm{N}$ and G. luteum (1.26 mg.g-1) at a dose of $40 \mathrm{mg} \mathrm{N}$. Figure 3 shows the same pattern relative to the content of glomalin between rhizosphere and mycorrhizosphere. The $\mathrm{N}$ dose of 20 to $30 \mathrm{mg}$ showed a higher content of glomalin than other doses. While the number of glomalin on mycorrizosphere was greater than on rizosphere and can reach $85 \%$.

This proved that the AMF hyphae showed very intensive development in the area of the mycorrhizosphere. This suggests that the excess supply of $\mathrm{N}$ can inhibit the development of AMF. As explained by Nouri et al. (2014). Symbiosis between plants and fungi is better as long as they are restricted by one of two main elements, namely $\mathrm{N}$ and $\mathrm{P}$. The $\mathrm{P}$ and $\mathrm{N}$ related pathways interact, and that the AMF promoting effect of the low $\mathrm{N}$ supply is dominant over the AMF suppressive effect of high $\mathrm{P}$ supply. Excess availability of $\mathrm{P}$ or $\mathrm{N}$ can inhibit the development of AMF. A systemic effect that depends on the nutritional status of the shoot.

\section{DISCUSSION}

\section{Response relationship of AMF on growth and nutrient content}

Arbuscular Mycorrhizal Fungi showed different responses to the growth of plants, especially the effect of different doses of organic $\mathrm{N}$ as a source of $\mathrm{N}$ and other nutrients. Increasing the dose of organic $\mathrm{N}$ affect root colonization, the content of $\mathrm{N}$ and $\mathrm{P}$, the ratio $\mathrm{S}: \mathrm{R}$ and mycorrhizal growth response. In this study, the optimal dose of organic $\mathrm{N}$ was $30 \mathrm{mg}$, and increasing $\mathrm{N}$ application to $40 \mathrm{mg}$ showed a negative influence on plant growth and development of the AMF. The nutrient status affected AMF colonization (Nouri et al., 2014; Carbonnel and Gutjahr, 2014), where plants control the degree of AMF colonization depending on their nutritional status and it has been repeatedly reported that under high $\mathrm{Pi}$ supply, AMF development is repressed (Balzergue et al., 2010; Breuillin et al., 2010; Balzergue et al., 2013). This suppression of high $\mathrm{P}$ on root colonization by AMF is partially overruled by $\mathrm{N}$ starvation, and to a lesser extent by potassium, calcium or iron starvation (Nouri et al., 2014). This has implications for fungal and plant control of resource exchange in the AMF symbiosis (Fellbaum et al., 2012). The nutriens $\mathrm{P}$ and nitrate can potentially exert negative reegulation on AMF colonization (Nouri et al., 2014).

Our results show that the optimal dose of organic $\mathrm{N}$ can support the development of AMF and plant growth by producing glomalin better. Hodge and Fitter (2010) explains that the presence of organic materials encourage more aggressive colonization of roots, where a large amount of $\mathrm{N}$ from organic sources mined for the metabolic needs of the AMF and partly transferred it to the host (Hodge et al., 2001; Leigh et al., 2009; Hodge and Fitter, 2010). The N from organic sources accessed by AMF is used for the synthesis of glomalin, where the $\mathrm{N}$ form of nitrate and ammonium used in the AMF symbiosis includes the synthesis of arginine in the extraradical mycelium. Arginine is transferred to the intraradical mycelium and it is broken down to release $\mathrm{N}$ for transfer to the host plant (Tian et al., 2010). The $\mathrm{N}$ transferred to the host plant is only about 3\% and the rest is used by AMF (Leigh et al., 2009; Hodge and fitter, 2010). Hosts provide fungus with $\mathrm{C}$ in the form of sucrose to encourage the transfer of $\mathrm{P}$ and $\mathrm{N}$ to plants in symbiosis AMF in return (Tian et al., 2010; Fellbaum et al., 2012; Nouri et al., 2014). 


\section{The role of organic $N$ to glomalin production}

Carbon is transferred to the fungus for the synthesis of glomalin. Wu et al., (2014) reported that a highly positive correlation of root glomalin with root glucose and sucrose. Glomalin is a N-linked glycoprotein combined in hyphae and spore walls of AMF in both soils and roots (Wright and Upadhyaya, 1996; Rosier et al., 2008). We assume that the synthesis of glomalin by AMF occur from assimilation between arginine derived from fungus, and glucose from the host to form glomalin. Glomalin production and hyphal growth are dependent upon photosynthetic $\mathrm{C}$. Increasing the supply of $\mathrm{N}$ and $\mathrm{P}$ to the host pushed supply of $\mathrm{C}$ to fungus (Fellbaum et al., 2012). In this study glomalin production was highest in the dose of $20 \mathrm{mg} \mathrm{N}$ to G. luteum and $30 \mathrm{mg}$ for G. versiforme (Fig. 4), relating to the contribution $\mathrm{N}$ in the host (Fig. 3). Increased $\mathrm{N}$ application on crops increased supply of $\mathrm{C}$ to fungus, so benefited the symbiosis with AMF to improve glomalin (Fig. 2). Therefore, AMF hyphae rich in $\mathrm{N}$, where intraradical mycelium $\mathrm{N}$ concentration reaches 4-7 times from the top of the plant, and even 10 times higher than the roots of plants (Hodge and Fitter, 2010). High $\mathrm{N}$ concentration in the hyphae is the fact that glomalin as hyphae and spore wall constituent AMF (Driver et al., 2005) is a source of $\mathrm{N}$ to the soil (Rillig, 2004; Rillig et al., 2001; Lovelock et al., 2004a).

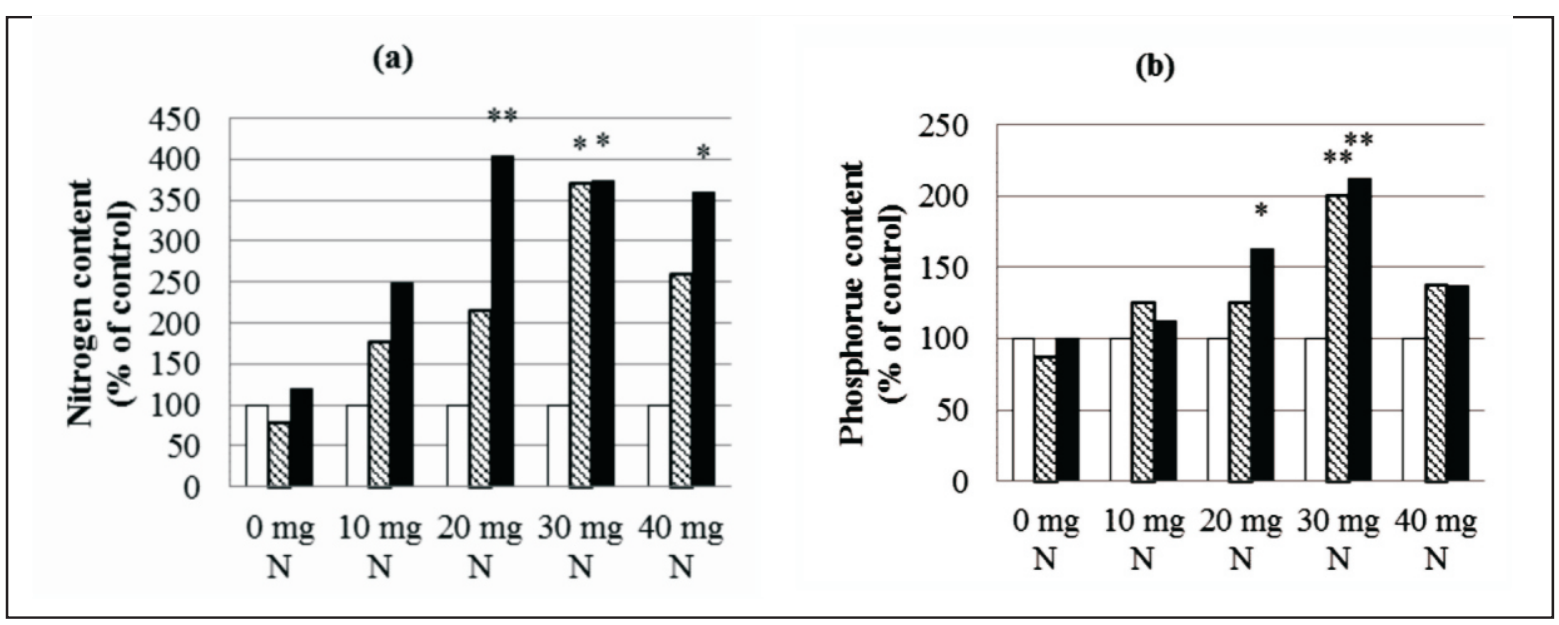

Figure 3. AMF increases nutrient content of plants with $\mathrm{N}$ organic tithonia. Asterisks indicate significant differences between non-mycorrhizal controls (white columns), G. luteum (orange columns) and G. verruculosum (brown columns). (a) increased $\mathrm{N}$ content of plants. (b) increased $\mathrm{P}$ content of plants. Values are expressed relatif to the non-mycorrhizal controls that were set to $100 \%$ for each $\mathrm{N}$ organic treatment.

Our results proved that the total glomalin best obtained through the provision of a dose of 20 to 30 mg N. This illustrates the development of AMF colonization, as described Wright et al. (1996) and Rosier et al. (2008), that glomalin as an indicator to measure the AMF colonization in plants. AMF development can be explained from the measurement of total glomalin which is a representation of the extraradical mycelium growth. Total glomalin in this study between 1.14 to $2.6 \mathrm{mg} . \mathrm{g}^{-1}$, which is higher than the previous pot experiment results (Eddiwal et al., 2014). Testing of nine species of AMF were isolated from Ultisol produces total glomalin 0.18 up to $1.29 \mathrm{mg} \cdot \mathrm{g}^{-1}$ media. These results are the lowest in the range reported by Wright and Upadhyaya (1998), which is 1 to $21 \mathrm{mg} \cdot \mathrm{g}^{-1}$ soil on thirty-seven soil from five different locations. On the other hand, the concentration of glomalin in the pot experiment by Antibus et al. (2006) reported to range from $1-5.5 \mathrm{mg} \cdot \mathrm{g}^{-1}$ soil. This is also confirmed by Lovelock et al. (2004b) that glomalin concentration is low for the pot experiment. 


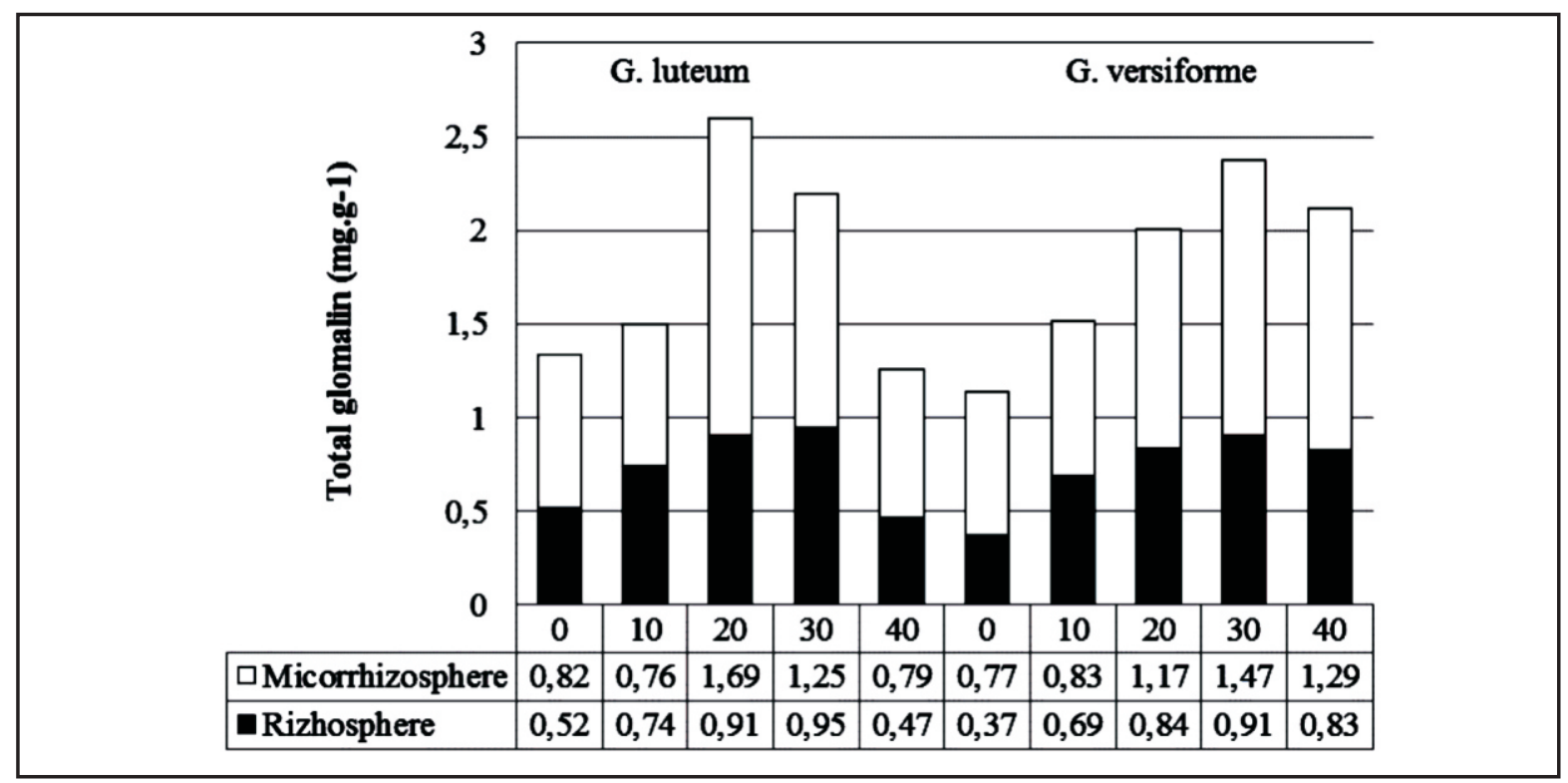

Figure 4. The content of media-influenced glomalin dose of organic N inoculated with G. luteum and G. versiforme on mycorrizosphere and rizosphere.

\section{CONCLUSIONS}

$\mathrm{AMF}$ and organic materials encourage root colonization and plant growth. The supply of $\mathrm{N}$ from organic sources for AMF has produced a positive mycorrhizal growth response, and was accompanied by an increase in the supply $\mathrm{N}$ and $\mathrm{P}$ to the plant host. On the other hand, the organic $\mathrm{N}$ application also increases the production of glomalin, where the optimal dose of $\mathrm{N}$ is 20 to $30 \mathrm{mg}$ to produces glomalin better. Further study of organic N supply from other sources for the AMF needs to be conducted, to determine the effect on crops and increased production of glomalin.

\section{ACKNOWLEDGMENTS}

The authors would like to thank the Director of the Postgraduate University of Andalas on BPPDN bursary or scholarship assistance for the implementation of this research, as well as the support of the Partnership Program KKP3N of Research and The development of Agriculture, Ministry of Agriculture Republic of Indonesia in the 2013 budget.

\section{REFERENCES}

Antibus, R.K., C. Lauber, R.L. Sinsabaugh, and D.R. Zak. 2006. Responses of Bradford-reactive soil protein to experimental nitrogen addition in three forest communities in northern lower Michigan. Plant Soil. 288:173-187.

Balzergue, C., V. Puech-Pages, G. Becard and S.F. Rochange (2011). The regulation of arbuscular mycorrhizal symbiosis by phosphate in pea involves early and systemic signalling events. Journal of Experimental Botany. $62: 1049-1060$.

Balzergue, C., M. Chabaud, D.G. Barker, G. Becard and S.F. Rochange (2013). High phosphate reduces host ability to devvelop arbuscular mycorrhizal symbiosis without affecting root calcium spiking responses to the fungus. Frontiers in Plant Science, $4: 1-15$. doi: 10.3389/fpls2013.00426. 
Breuillin F, J. Schramm, M. Hajirezaei, A. Ahkami and P. Favre (2010). Phosphate systematically inhibits development of arbuscular mycorrhiza in petunia hybrida and represes genes involved in mycorrhizal functioning. Plant Journal. 64 : 1002-1017.

Bronick, C. J dan Lal, R. (2005). Soil structure and management : a review. Goederma, 124 : 3-22.

Cappellazzo, G. Laufranco L. Lanfranco L. Fitz M. Wipf D. dan Bonfante P. 2008. Characterization of an amino acid permease from the endomycorrhizal fungus Glomus mosseae. Plant Physiologist. $147: 429-437$.

Carbonnel, S. and C. Gutjahr (2014). Control of arbuscular mycorrhiza development by nutient signals. Frontiers in Plant Science, 5 : 1-5, doi:10.3389/fpls.2014.00462.

Curaqueo, G. E. Acevedo, P. Cornejo, A. Sequel, R. Rubio and F. Borie. (2010). Tillage effect on soil organik matter mycorrhizal hyphae and aggregates in a Mediterranean agroecosystem. R. C. Suelo Nutr.. Veg. 10 (1): 12 - 21.

Driver, J. D., W. E. Holben and M. C. Rillig. (2005). Characterization of glomalin as a hyphal wall component of arbuscular mycorrhizal fungi. Soil Biology and Biochemistry. 37: $101-106$.

Eddiwal, A. Saidi, Ismon, L., E.F. Husin and A. Rasyidin (2014). Potential selection of arbuscular mycorrhizal fungi (AMF) indigenous Ultisol through the production of glomalin. Jurnal Tanah Tropika, 19(3): (September 2014).

Fellbaum, C.R., J.A. Mensah, P.E. Pfeffer, E.T. Kiers and H. Bucking (2012). The role of carbon in fungal nutrient uptake and transport. Plant Signaling \& Behavior 7:11. 1509-1512. http://dx.doi.org/10.4161/psb.22015.

Giovannetti, M and Mosse, B. (1980). An evaluation of techniques for measuring vesicular arbuscular mycorrhizal infection in roots. New Phytol. $84: 489$ - 500.

Govindarajulu, M. Pfeffer P. E. Jin H. Abubaker J. Douds D. D. Allen J. W. Bucking H. Lammers P. J. dan Hill Y. S. 2005. Nitrogen transfer in the arbuscular mycorrhizal symbiosis. Nature. Vol. 435 : 819-823.

Guether, M. Neuhauser B. Belestrini R. Dynouski M. Ludewig U dan Bonfante P. 2009. A mycorrhizal specific ammonium transporter from lotus japonicus acquires nitrogen released by arbuscular mycorrhizal fungi. Plant Physiology. Vol. 150:73-83.

Hodge, A. Campbell C. D. dan Fitter A. H. 2001. An arbuscular mycorrhizal fungus accelerates decomposition and acquires nitrogen directly from organic material. Nature. Vol. $413: 297-299$.

Hodge, A. and A. H. Fitter. 2010. Substantial nitrogen acquisition by arbuscular mycorrhizal fungi from organik meterial has implications for N cycling. PANAS. 107 (31) : 13754-13759.

Hoorman J. J., J. C. de Moraes (Juca) Sa and R. Reader. 2011. The Biology of Soil Compaction. American Society of Agronomy. Crops and Soils Magazine (July-August 2011) : 4 - 10.

Kobae, Y. Tamura Y. Takai S. Banba M. dan Hata S. 2010. Localized expression of arbuscular mycorrhiza-inducible ammonium transporters in soybean. Plant Cell Physiol. 51 (9) : 1411-1415.

Kormanik PP., and McGraw AC. 1982. Quantification of vesicular-arbuscular mycorrhizae in plant roots. In: Schenk NC, ed. Methods and principals of mycorrhizal research. St, Paul, USA: American Phytopathological Society, 37-46.

Leigh J., Hodge A., and Fitter A. H. 2009. Arbuscular mycorrhizal fungi can transfer substantial amounts of nitrogen to their host plant from organic material. New Phytologist, 181: 199-207.

Lovelock, C.E., S.F. Wright, D.A. Clark, and R.W. Ruess. 2004a. Soil stocks of glomalin produced by arbuscular mycorrhizal fungi across a tropical rain forest landscape. Journal of Ecology, Vol. 92 : $278-287$.

Lovelock, C.E., S.F. Wright, and K.A. Nichols. 2004b. Using glomalin as an indicator for arbuscular mycorrhizal hyphal growth: an example from a tropical rainforest soil. Soil Biol. Biochem. 36:1009-1012. 
Nichols, K.A. and S.F. Wright. 2004. Contributions of fungi to soil organic matter in agroecosystems. p. 179-198. In F. Magdoff and R.R. Weil (eds.), Soil Organic Matter in Sustainable Agriculture. CRC Press, Florida.

Nouri, E., F. Breuillin, U. Feller and D. Reinhardt (2014). Phosphorus and nitrogen regulate arbuscular mycorrhizal symbiosis in petunia hybrida. Plos One, 9(3): 1-14. doi:10.1371/journal.pone.0090841.

Osaki, M., T. Watanabe and T. Tadano. 1997. Beneficial effect of aluminum on growth of plants adapted to low pH soils. Soil Science Plant Nutr. 43 (3) 551 - 563.

Rillig, M. C., S. F. Wright, K. A. Nichols, W. F. Schmidt and M. S. Torn. 2001. Large contribution of arbuscular mycorrhizal fungi to soil carbon pools in tropical rain forest. Plant and Soil. 233 : 167177.

Rillig, M. C. 2004. Arbuscular mycorrhizae, glomalin and soil aggregation. Can. J. Soil Sci. 84 : 355 363.

Rosier, C. L., J.S. Piotrowski, A.T. Hoye and M.C. Rillig (2008). Intraradical protein and glomalin as a tool for quantifying arbuscular mycorrhizal root colonization. Pedobiologia 52:41-50.

Six, J., E. T. Elliott and K. Paustian. 2000. Soil structure and soil organic matter : II. A normalized stability index and the effect of mineralogy. Soil Science Soc. Am. J. 64 : 1042-1049.

Subowo, G. 2010. Strategi efisiensi penggunaan bahan organik untuk kesuburan dan produktivitas tanah melalui pemberdayaan sumberdaya hayati tanah. Jurnal Sumberdaya Lahan Vol. 4 (1) : 13 25.

Tian, C., B. Kasiborski, R. koul, P.J. Lammers, H. Bucking and Y. Shachar-Hill (2010). Regulation of the nitrogen transfer pathway in the arbuscular mycorrhizal symbiosis: Gene characterization and the coordination of expression with nitrogen flux. Plant Physiology 153:1175-1187.

USDA_Bio-Rad Bradford Total Protein Assay with Sodium Pyrophosphate Modification. Authors (Bradford, 1976; Nichols and Wright, 2004 \& Wright et al., 2006) [Online]. Available at www.ars.usda.gov/.../Bradford\%20Total\%20Protein\%20Assay.pdf

USDA_GLOMALIN EXTRACTION-USDA. Glomalin Extraction with Sodium Pyrophosphate. Authors (Rillig, 2004; Rosier et al., 2007; and Rillig, 2003; Wright et al., 1996; Wright and Jawson, 2001; Wright, Nichols, \& Schmidt, 2006; Wright \& Upadhyaya, 1996; \& Wright \& Upadhyaya, 1998) [Online]. Available at www.ars.usda.gov/.../ad_hoc/54450000Glomalin/ Glomalin\%20Extraction.pdf.

Wright, S. F and A. Upadhyaya. 1996. Extraction of an abundant an unusual protein from soil and comparison with hyphal protein of arbuscular mycorrhizal fungi. Soil Science. 161 (9) : 575-586.

Wright, S. F. and A. Upadhyaya. 1998. A survey of soil for aggregate stability and glomalin, a glycoprotein produced by hyphae of arbuscular mycorrhizal fungi. Plant and Soil. 98:97 - 107.

Wright, S. F., M. Franke-Snyder, J. B. Morton and A. Upadhyaya. 1996. Time course study and partial characterization of a protein on hyphae of arbuscular mycorrhizal fungi during active colonization of roots. Plant Soil. $181: 193-203$.

Wright, S.F. and A. Upadhyaya. 1999. Quantification of arbuscular mycorrhizal activity by the glomalin concentration on hyphae. Mycorrhiza. 8:283-285.

Wright, S. F., K. A. Nichols, L. Jawson, L. McKenna and A. Almendras. 2001. Glomalin-A manageable soil glue. Soil Science Society of America Special publication Book Chapter. 21 October 2001. ARS.USDA.gov.

Wu, Q.S., S. Wang, M.Q. Cao, Y.N. Zou and Y.X. Yao (2014). Tempo-spatial distribution and related functionings of root glomalin and glomalin-related soil protein in a citrus rhizosphere. J. Anim. Plant Sci. 224 (1): 245-251. 